\title{
Investigation of the Effect of R\&D, Education and Health Expenditures on Economic Growth by Panel Data Analysis Method
}

\author{
Durmuş GÖKKAYA (https://orcid.org/0000-0002-6713-1748), Yozgat Bozok University, Turkey; \\ durmus.gokkaya@yobu.edu.tr \\ Osman ŞENOL (https://orcid.org/0000-0001-5626-2921), Süleyman Demirel University, Turkey; \\ osmansenol@sdu.edu.tr \\ Ümit ÇIRAKLI (https://orcid.org/0000-0002-3134-8830), Yozgat Bozok University, Turkey; \\ umit.cirakli@bozok.edu.tr

\section{Ar-Ge, Eğitim ve Sağlık Harcamalarının Ekonomik Büyüme Üzerindeki Etkisinin Panel Veri Analizi Yöntemiyle Değerlendirilmesi}

\begin{abstract}
This study aims to reveal the effects of R\&D, education, and health expenditures on economic development. For this purpose, the study examines the 2000-2019 data of 45 countries in the middleupper-income and high-income country groups by panel data analysis method. Errors encountered in panel data basic assumption tests were corrected with Driscoll-Kraay standard errors. As a result, it has been determined that a one-unit increase in education and health expenditures contributes more to economic growth than one unit. In contrast, $R \& D$ expenditures have a minor positive effect on economic growth in the short run but more in the long run.
\end{abstract}

Keywords

R\&D, Economic Growth, Education Expenditure, Health Expenditure, Panel Data Analysis.

JEL Classification Codes : E00, I00, I15.

\section{$\ddot{\mathbf{O} z}$}

$\mathrm{Bu}$ çalışma Ar-Ge, eğitim ve sağlık harcamalarının ekonomik gelişme üzerinde etkileri ortaya koymayı amaçlamaktadır. Bu amaçla çalışma orta-üst gelir ve yüksek gelirli ülke gruplarında yer alan 45 ülkenin 2000-2019 verilerini panel veri analiz yöntemi ile incelemektedir. Panel veri temel varsayım testleri sonucu karşılaşılan hatalar Driscool-Kraay standart hatalar ile düzeltmiştir. Çalışma sonucunda eğitim ve sağlık harcamalarındaki bir birimlik artışın ekonomik büyümeye bir birimden daha fazla katkı sağladığı, Ar-Ge harcamalarının ise ekonomik büyüme üzerinde kısa vadede pozitif etkisi az iken, uzun vadede daha fazla olduğu belirlenmiştir.

Anahtar Sözcükler : Ar-Ge, Ekonomik Büyüme, Eğitim Harcaması, Sağlık Harcamas1, Panel Veri Analizi. 
Gökkaya, D. \& O. Şenol \& Ü. Çıraklı (2021), "Investigation of the Effect of R\&D, Education and Health Expenditures on Economic Growth by Panel Data Analysis Method", Sosyoekonomi, 29(50), 95-108.

\section{Introduction}

The number of educated people within the human social capital plays an important role in the growth and development of countries. For this reason, education is among the most critical issues of a country. Education provides important contributions to countries in providing a competitive advantage with the increase in competition conditions in every field in the globalizing world. It is possible to produce high-tech products in many sectors and areas, especially health, defence, and industry, and sell them in world markets with welleducated human resources. In addition, education performs an important function on many subjects such as increasing the qualifications of employees, producing and using information, using human resources effectively and efficiently, reaching the level of the information society, and ensuring that individuals gain awareness of healthy living behaviour and give importance to their health.

In parallel with the developments in the educational status, it is a known fact that individuals contribute to themselves individually, such as the rate of finding employment, working with high wages, working in their fields of expertise, and high performance and productivity in this direction. At the same time, it makes a significant contribution to everyone in using an educated and trained workforce in the market, business centres, and important state institutions (health, education, defence, and other institutions). For these and many other reasons, it is developed and developing countries prioritize education policies. In this respect, it can be stated that there is often a direct-way relationship between the increase in education levels and the level of development of a country. As a result, it is understood that education has vital importance in countries' economic growth and development.

In addition to education, research and development (R\&D) activities also play an important role in increasing the competitiveness of a country and providing a competitive advantage. The importance of R\&D and education investments in the production of high and advanced technological products is an undeniable fact. When we look at developed countries, it is known that they allocate significant shares from their national income in these two areas. When looking at the foundations of innovation, technological advancement, and producing products that create added value, it is seen that there are R\&D activities. In addition, it is a fact that $R \& D$ activities play an essential role in many areas and product ranges, such as revealing new production processes, reducing costs, preventing occupational accidents, increasing employees' productivity and performance, and improving living standards. It can be stated that the economic gains it brings along with the due importance given to R\&D are noticed early by developed countries. It is known that economic growth is achieved by exporting both technological and value-added products produced as a result of R\&D activities. Therefore, maintaining economic development and growth by investing more in education and R\&D should be among the main goals of countries.

On the other hand, one of the development indicators of a country or society is health. When the health indicators of economically developed countries and the country's 
Gökkaya, D. \& O. Şenol \& Ü. Çraklı (2021), "Investigation of the Effect of R\&D, Education and Health Expenditures on Economic Growth by Panel Data Analysis Method", Sosyoekonomi, 29(50), 95-108.

population's health level are examined, they are in a better position than undeveloped or developing countries. This can be stated that it is directly proportional to the high investments and expenditures in health. In addition, people who are a country's human capital must be healthy and sound mentally and physically. Investments and expenditures made in education ensure that individuals are mentally healthy, while investments and expenditures made in health ensure that individuals are physically healthy. In this context, it is evident that individuals who are developed and healthy both mentally and physically will contribute to the country's economic growth and development in their economic activities. Spending on health, especially those made on preventive and curative services, can be the locomotive or engine of the economy to ensure that individuals are born and healthily maintain their lives for a long time because health investments and expenditures are of vital importance in terms of contributing to the long and healthy life of individuals, decreasing infant and maternal mortality rates and increasing the population together with the reduction of accidental deaths. Thus, due to these investments and expenditures, it is evident that individuals living healthier and longer will contribute to a country's economic growth.

As stated above, it is important to measure the impact of $R \& D$, education, and health expenditures on countries' economic growth at the macro level. In this direction, this study was carried out to determine the impact of countries' education, $R \& D$, and health expenditures on economic growth using panel data econometric methods. Although there are differences in the sample, variable, and periods covered by the study in the literature, similar studies, and their findings are given below.

\section{Literature Review}

Various studies have been conducted with different period data sets that impact economic growth when the literature is examined. When the international literature is searched, there are various studies on the variables of $R \& D$, education, and health expenditures. However, most of the studies on economic growth deal with one variable or two variables.

Looking at the literature, studies stand out examining the relationship between economic growth based on the R\&D variable (Sylwester, 2001; Pessoa, 2010; Bozkurt, 2015; Mansfield, 1972; Stokey, 1995; Goel et al., 2008; Aghion \& Howitt, 1996; Akcali \& Sismanoglu, 2015; Griffith, 2000; Falk, 2007). Looking at the relationship between economic growth and education variables, there are a lot of studies (Barro, 2001; Gylfason, 2001; Mercan \& Sezer, 2014; Gyimah-Brempong et al., 2006; Mariana, 2015; Chatterji, 1998; Romer, 1989; Hongyi \& Huang, 2009; Hanushek \& Woessmann, 2010; Stevens \& Weale 2004) examining this relationship. Finally, when the health expenditures variable is considered, studies are investigating the relationship between economic growth and health expenditure (Bhargava et al., 2001; Elmi \& Sadeghi, 2012; Wang, 2011; Bakare \& Olubokun, 2011; Piabuo \& Tieguhong, 2017; Kurt, 2015; Rivera \& Currais, 1999; Mayer, 2001; Heshmati, 2001; Mishra \& Mishra, 2015). 
Woo et al., (2017) investigated the effect of education and R\&D investments on regional economic growth in a study examining the regional differences of South Korea covering 16 different cities or regions using panel data analysis method with data between 1997-2009. As a result of the study, it has been determined that education and R\&D expenditures positively affect economic growth. In addition, education and R\&D expenditures have been observed to reduce regional inequalities. Tamang (2011) examines the relationship between education expenditures and economic growth in the Indian economy in his study. An econometric model was applied with time series analysis based on the data set between 1980-2008. As a result of the study, it was seen that there is a longterm relationship between education expenditures and economic growth. GyimahBrempong et al. (2006), using panel data for 1960-2000, examined the effect of higher education human capital on economic growth in African countries. As a result of the research, it was determined that all education levels, including higher education, have a positive and statistically significant effect on the growth rate of per capita income in African countries.

Falk (2007) conducted a study to estimate the impact of R\&D investment on longterm economic growth. A dynamic empirical growth model was tried to be predicted using the panel data analysis method with the data covering the OECD countries and belonging to the years 1970-2004. According to the results of this study, it has been determined that both the ratio of $R \& D$ expenditures of commercial enterprises to GDP and the share of R\&D investments in the high technology sector has strong positive effects on GDP per capita and GDP per hour worked in the long run. In his study, Mariana (2015) investigated the causality relationship between education, significantly higher education, and economic growth in Romania, based on 1980-2013. A vector error correction model is used to analyse the study's long-term relationship between education and economic growth. As a result of the econometric analysis, it has been seen that higher education has a positive effect on economic growth.

In the literature, some results in some of the few studies show that the effect or relationship of $R \& D$ and education on economic growth is not significant. Samimi and Alerasoul (2009) examined the impact of R\&D on the economic growth of developing countries in their research. The research was conducted using the panel data regression model with a sample of 30 developing countries over the data for the period 2000-2006. Considering the findings obtained as a result of this research, it is seen that there is no significant positive effect between R\&D expenditures and economic growth in the countries included in the sample. Barro (2001) conducted a study based on the education variable, one of the human capitals he saw as the determinant of economic growth. The study examined the effects of human capital, especially education, on economic growth with panel data covering 1960-1995 and 100 countries. According to the results of the study, it was determined that there is a positive relationship between education and growth between the number of students at secondary and higher education levels in adult male students or the average school acquisition; This situation was found to have a negative or insignificant relationship among female students at the same level. The researcher interpreted this result 
as that women with higher education are not well used or employed in the labour market of many countries.

On the other hand, Hongyi and Huang (2009) reveal an empirical analysis by considering both health and education, human capital, in their study in China. Panel data models were used in the study based on provincial-level data covering the period 1978-2005. According to the study's findings, it has been determined that both health and education expenditures have positive and significant effects on economic growth. Heshmati (2001) examined the relationship between per capita health expenditures and economic growth, using the causality test in the context of the Solow model, based on the data of OECD countries between 1970-1992. As a result of the study, it was seen that health expenditures, that is, health expenditure per capita, had a positive effect on economic growth. Chang and Ying (2006), in their study covering 15 OECD countries, found that there is a positive and significant relationship between health expenditures and economic growth. Wang (2011) examined the causality between the increase in health expenditures and economic growth. The total health expenditure data of 31 countries from 1986-2007 were analysed by panel regression and quantitative regression methods. As a result of the study, it was found that the effect of health expenditure increases on economic growth in countries with medium and high levels of economic growth was found to be positive.

On the other hand, Güven, Şimşek (2018) found that health expenditures in MENA countries on economic growth are negative. Şen, Kaya, and Alpaslan (2018) examined the causality relationship between eight developing countries' health, education, and economic growth. They found that while there was a positive causality relationship in only two countries, the causality relationship was negative for one country (Indonesia).

When the studies using different samples and variables are examined, it is seen that R\&D, education, and health expenditures positively affect economic growth in most studies. The findings of this study are similar to the findings of the study in the literature. In this study, countries in different sample groups were examined together, and the relationships between these variables were examined holistically. The methodological part of the research is given below.

\section{Data and Methodology}

\subsection{Objective, Scope, and Method of the Research}

The study aims to measure education and R\&D expenditures, especially health expenditures, on economic growth. Accordingly, the relationship between the specified variables and the economic growth variable will be tested using the panel data analysis method. The analysis of the data was performed using EViews 10 and Stata 15.0 package programs. 


\subsection{Model and Data}

This study was carried out to determine the relationship between economic growth, the most important variable of a country, and education, health, and $R \& D$ expenditures. While choosing the study's sample group, the World Bank's classification of countries according to income groups was considered. The country group included in the study included upper-middle-income countries and high-income countries. On the other hand, many variables affect the economic growth different from those mentioned in the study. However, in this study, the relations between the specified variables of the countries included in the sample from the developed and developing country groups and economic growth are tested. Therefore, the variables not included in the study on economic growth will be included in the model within the error term.

Considering the World Bank's country classification within the scope of the research, 132 countries constitute the universe of the research. However, the missing data for the countries caused the sample group to be narrowed. Forty-five countries were included in the study in line with the availability of data. In the study, the effect of these variables on economic growth was tried to be tested in upper middle income and high-income countries. When the literature was examined, it was seen that similar studies were conducted using different variables in different sample groups. The studies mentioned above were examined in the literature, and it was also desired to select the most appropriate variable to reflect the purpose of the study. The data types of the variables are annual. The time dimension of the study covers the period 2000-2019.

Table: 1

Variables of Study

\begin{tabular}{|c|c|}
\hline Variable & Symbol \\
\hline Gross Domestic Product & lngdp \\
\hline Education Expenditures & dlneducationexp \\
\hline R\&D Expenditures & dlnrdexp \\
\hline Health Expenditures & dlnhealthexp \\
\hline
\end{tabular}

The variables to be used in the model are specified in Table 1. First, the model's GDP variable, the dependent variable, was examined, and the stationarity check was made. The GDP variable was stable at the level, and its natural logarithm was taken to reduce its numerical value. The natural logarithmic transformation was first applied to the education expenditure variable, and it was found to be stationary at the first level. Since the series became stationary at the first level, the first level version was included in the model. Since the R\&D and health expenditure series became stable at the first level, they were included in the model with their first differences.

Since there is only one dependent variable in the study, a single model will be created. In the model to be created, the GDP variable is used to represent economic growth and is included in the model as a dependent variable. Other variables specified were included in the model as independent variables. The mathematical representation of the created model is as follows: 
Gökkaya, D. \& O. Şenol \& Ü. Çıraklı (2021), "Investigation of the Effect of R\&D, Education and Health Expenditures on Economic Growth by Panel Data Analysis Method", Sosyoekonomi, 29(50), 95-108.

$$
\begin{aligned}
& \Delta L N G D P_{i t}=C+\sum_{j=1}^{p i} \lambda_{i j} \Delta L N H E A L T H E X P_{i, t-j}+\sum_{j=0}^{q i} \delta_{i j} \Delta L N E D U C A T I O N E X P_{i, t-j}+ \\
& \sum_{j=0}^{q i} \varphi_{i j} \Delta L N R D E X P_{i, t-j}+\varepsilon_{i t}
\end{aligned}
$$

The output of the Model:

lngdp $=1.37023429653 *$ dlnheawlthexp $+0.739014482971 *$ dlneducationexp +

$0.0722866026261 * \operatorname{dln} r d e x p+24.1513547903+$ eqn_01_efct

The left side of the specified equation gives the dependent variable. On the right side of the equation, " $\Delta$ " is the first difference operator, "LN" is the logarithm of the series, and " $\varepsilon_{i \mathrm{it}}$ " is error term with zero mean and variance constant within each unit, " $i$ " is the crosssection and finally " $t$ " is the information about the period. Although different variables are used when estimating the dependent variable in panel data analysis models, some variables affect the dependent variable but cannot be measured or included. The effect of variables that we cannot predict within the model's scope or not included in the model is summed up in the error term.

\subsection{Determination of Panel Data Model Methods}

There are three basic approaches when creating a model in panel data analysis. These approaches are random model, fixed-effects model, and pooled panel data models. Which approach fits the model to be created will be determined with the help of relevant tests. In addition, panel data models are divided into micro and macro according to the number of periods covered. In this regard, Baltagi (2013: 1) classifies panels up to 20 periods as micro panels and panels with more than 20 periods as macro panels. Baltagi (2013) states that series in micro panels should not be seen as compulsory to provide stationarity and states that the stationarities of series should be ensured in macro panels. Since the number of periods of this research is 20 , the model to be created enters the micro panel. The tests to be made will also be carried out under micro panel assumptions.

\section{Findings}

This part of the study will check whether the basic assumptions are met before panel data modelling. The results of the preliminary hypothesis tests and the outputs of the latest model created will be included in this direction.

\subsection{Multiple Linear Connection Problem}

When creating panel data models, one of the most critical assumptions is that the model should not have a multiple linear connection problem. First of all, variables with high correlation should not be used within the same model. As Gujarati (2004: 342) stated, using variables that have a high correlation simultaneously, a multiple linear connection problem will be encountered. Different tests and methods have been developed to detect the multiple linear connection problem in the panel data models created. One of these methods is the Variance Inflation Factor (VIF). It is important to calculate the variables' VIF values and 
determine the variables above the threshold value. VIF values are accepted as a threshold value of 4 in some studies and 5 and 10 in some studies. The calculation of the VIF values of the variables is 1 / (1-R2) (Aç1kgöz et al., 2015: 427; Brien, 2007: 673). The R2 value is the power of independent variables to explain dependent variables in the model. Each variable is selected as a dependent variable for one time only. A model is created for each dependent variable, and R2 value is obtained. With the obtained R2 value, the VIF value for each variable is calculated.

Table: 2

\section{VIF Values of Variables}

\begin{tabular}{|c|c|c|}
\hline Variables & $\mathbf{R}^{2}$ & VIF Values \\
\hline Ingdp & 0.55 & 2.22 \\
\hline dlneducationexp & 0.47 & 1.88 \\
\hline dlnrdexp & 0.43 & 1.75 \\
\hline dlnhealthexp & 0.46 & 1.85 \\
\hline
\end{tabular}

VIF values of the variables are given in Table 2. When the VIF values of the variables are examined, no variable can create a multiple linear connection problem in the model. It is seen that all variables have VIF values lower than 4, which is the smallest critical value. Because the variable VIF values are lower than the threshold value, all variables will be included in the model. After testing the multiple linear connection problem in the model, it is necessary to determine which approach is valid in the model.

\subsection{Panel Data Model Identification Tests}

First, it is checked whether the classical model is suitable for the model. The test statistic is tested by comparing it with the $\mathrm{F}$ distribution table at $((\mathrm{N}-1=24,(\mathrm{~N}(\mathrm{~T}-1)-\mathrm{K})=$ 852 degrees of freedom). In other words, the classical model does not seem suitable for this model. In the next step, it is necessary to choose between fixed effects and random effects.

Table: 3

\section{Panel Data Model Identification Tests}

\begin{tabular}{|c|c|c|}
\hline \multicolumn{2}{|c|}{ Model 1 } & Probability \\
\hline & Statistic Value & 0.000 \\
\hline F-Fixed Effects & 45.86 & 0.000 \\
\hline Hausman Test & 55.40 & \\
\hline
\end{tabular}

As a result of the Hausman test conducted for the model, it is seen that the H0 hypothesis is rejected, and the random effects estimator is invalid, and the fixed effects estimator is valid. According to the test results obtained, the model was estimated with a fixed-effects approach. Autocorrelation, which is another assumption, should be controlled to obtain a robust model.

\subsection{Autocorrelation Test}

To obtain a robust model in panel data analysis, the model should not have an autocorrelation problem. The existence of autocorrelation in the model means that the error 
terms of the variables are related to each other. In such a case, correct estimator coefficients cannot be obtained. The presence of this problem should be tested, and, if any, necessary correction tests should be performed.

Table: 4

Results of Autocorrelation Tests

\begin{tabular}{|c|c|}
\hline Test & Model 1 \\
\hline Bhargava, Franzini, and Narendranathan's Durbin Watson Test & 0.3289 \\
\hline Baltagi-Wu locally best invariant test & 0.5436 \\
\hline
\end{tabular}

In Table 4, Durbin Watson and Baltagi-Wu autocorrelation test results of model 1 are given. These tests are recommended tests to test the presence of autocorrelation in the fixedeffects model. In both test types, the $\mathrm{H} 0$ hypothesis that the autocorrelation coefficients are zero is tested. The literature pointed out that autocorrelation is important if these test values are less than 2. From a different point of view, it is understood that there is an autocorrelation problem in the model since the test values in this model are much lower than 2 . This problem will be taken into consideration, and necessary correction tests will be applied. Another model that should be considered to obtain a robust and correct model is controlling heteroscedasticity.

\subsection{Heteroscedasticity Test}

In panel data studies, all models must be built on homoscedasticity. Therefore, homogeneity of variance should be tested for models. Since the fixed effects approach is adopted in the models, the Modified Wald Test, which gives the most accurate result in heteroscedasticity, was used.

Table: 5

\section{Result of Heteroscedasticity Test}

\begin{tabular}{|c|c|c|}
\hline Test & Model 1 & Probability \\
\hline & Chi $^{\mathbf{2}}$ & 0.0000 \\
\hline Modified Wald Test & 1449.89 & \\
\hline
\end{tabular}

When the Wald test result in Table 5 is examined, the H0 hypothesis is rejected, and it is seen that the variance varies according to the units. In other words, it is seen that there is heteroscedasticity in the model. Corrective tests will be carried out considering this problem. Another and last assumption for panel data modelling is to check whether there is cross-sectional dependency in the model.

\subsection{Cross-Section Dependency Test}

In Table 6, three different test results are given for the test of cross-sectional dependency of the model. The H0 hypothesis of all tests is established as there is no crosssectional dependency. 
Gökkaya, D. \& O. Şenol \& Ü. Çıraklı (2021), "Investigation of the Effect of R\&D, Education and Health Expenditures on Economic Growth by Panel Data Analysis Method", Sosyoekonomi, 29(50), 95-108.

Table: 6

Cross Section Dependency Test

\begin{tabular}{|c|c|c|}
\hline Test & Model 1 & Probability \\
\hline & Statistic & 0.000 \\
\hline Breusch-Pagan LM & 3838.241 & 0.000 \\
\hline Pesaran Scaled LM & 64.009 & 0.828 \\
\hline Pesaran CD & 0.216503 & \\
\hline
\end{tabular}

According to the results of Breusch-Pagan Lm and Pesaran Scaled LM tests, it is seen that there is cross-section dependence, whereas according to the Pesaran CD test, it is seen that there is no cross-section dependence. The presence of cross-sectional dependency in the model is accepted because the two tests give results that there is a cross-sectional dependency. In the case of autocorrelation, changing variance, and cross-section dependence in a panel data analysis model, Driscoll and Kraay estimator should be used to eliminate the effects of these three problems. Thanks to the Driscoll and Kraay robust correction test, the model will be free from the effects of these problems, and more resistant estimator coefficients will be obtained.

\subsection{Panel Data Results of Driscoll and Kraay Standard Error}

GDP variable was chosen as the dependent variable in Model 1. GDP is considered to be the most important indicator of a country's economic development level. On the other hand, the model uses education expenditure, health expenditure, and R\&D expenditure variables as independent variables. Whether Model 1 provides the basic assumptions for panel data analysis were checked one by one. As a result of the basic assumption tests of Model 1, it was seen that there was autocorrelation, variance, and cross-section dependence. Driscoll and Kraay tests were applied to eliminate the effects of these problems among the robust correction tests. Whether the model is meaningful is understood by looking at the $\mathrm{F}$ statistic and F probability values.

\section{Table: 7}

Panel Data Results of Driscoll and Kraay Standard Error for Model 1

\begin{tabular}{|c|c|c|c|c|}
\hline Dependent Variable & Period & Cross Section & Total Observation & \\
\hline lngdp & $2000-2019$ & 45 & 900 & Probability \\
\hline Variable & Coefficient & $\begin{array}{c}\text { Drisc/Kraay } \\
\text { Standard Error }\end{array}$ & t-statistic & 0.001 \\
\hline dlneducationexp & 1.086332 & 0.288182 & 3.77 & 0.000 \\
\hline dlnhealthexp & 1.296649 & 2698781 & 4.80 & 0.000 \\
\hline dlnrdexp & 0.074811 & 0.0657649 & 4.29 & 0.000 \\
\hline $\mathrm{C}$ & 24.83612 & 0.7360859 & 33.74 & Prob (F-Statistic): 0.000 \\
\hline $\mathrm{R}^{2}: 0.17$ & \multicolumn{2}{|c}{ F-statistic: 15.54} & \multicolumn{2}{c}{} \\
\hline \multicolumn{2}{|r}{}
\end{tabular}

In this model, it is seen that the F statistic value is 15.54 , while the F probability value is 0.000 . In other words, it is seen that the model is significant as a whole. It is seen that the $\mathrm{R} 2$ value is 0.17 in the model. In other words, the power of independent variables to explain the dependent variable is seen as 0.17. Many variables affect the GDP of a country apart from those variables. This study was conducted to determine the relationship between the independent variables specified in the model and the GDP variable, and other variables were 
Gökkaya, D. \& O. Şenol \& Ü. Çraklı (2021), "Investigation of the Effect of R\&D, Education and Health Expenditures on Economic Growth by Panel Data Analysis Method", Sosyoekonomi, 29(50), 95-108.

ignored. When similar studies in the literature are examined, it is seen that $\mathrm{R}^{2}$ values are close to each other.

It is seen that all of the independent variables included in the model are in a positive relationship with the dependent variable. In other words, it can be said that a positive development in independent variables may affect economic growth positively, and a negative development may negatively affect economic growth. It is foreseen that One unit of expenditure to be made by the country's administration for educational infrastructure and training needs can contribute to the economic growth by 1,086 units. It is estimated that GDP may increase by 1.29 units for a one-unit increase in health expenditures, resulting in a 1.29 unit increase in GDP. It is predicted that each unit of increase in R\&D expenditures can increase 0.07 units in GDP. On the other hand, it is seen that the constant term in the model is significant, and the estimator coefficient is also relatively high.

\section{Conclusion}

Today, the most crucial goal of all countries and communities is to develop economically and prosper. For a society to reach an excellent economic level, it needs a healthy society, a trained workforce to produce, and goods and services with high added value. Although other factors are needed apart from these, the most important factors are that society is educated, healthy, and spends on R\&D to produce value-added products and services. For these reasons, it is important to determine the relationship between the GDP level of health expenditures, education expenditures, and R\&D expenditures of uppermiddle-income countries and high-income countries.

In the model, the estimator coefficient is the minor R\&D expenditure. It takes a very long process to produce products and services with a high added value anywhere. Every investment or effort made does not yield immediate results. On the other hand, when countries are analysed globally, it is known that countries with a certain economic level make investments for R\&D expenditures. Today, in many countries, due to the short term of office of public administrators, resource allocation for areas that cannot be achieved immediately in the short term is limited. R\&D expenditures are long-term investments, and their benefits and effects arise in the long term. In an environment where the country's resources are limited, long-term investments are inevitably postponed, focusing on shortterm solutions. Another variable is healthcare spending. It is seen in the literature that many studies have been conducted between health expenditures and economic development. When these studies are examined, it is seen that there is a positive relationship between economic growth and health expenditures in some studies.

In contrast, a negative relationship is found in some studies. Meeting the healthcare needs of people and having the chance to intervene in health problems promptly contributes to the formation of a healthier society. In a healthier society, it is known that while absenteeism is less, work efficiency and work commitment levels are high. Accordingly, in this study, it is estimated that in one unit of expenditure for health expenditures, the 
Gökkaya, D. \& O. Şenol \& Ü. Çıraklı (2021), "Investigation of the Effect of R\&D, Education and Health Expenditures on Economic Growth by Panel Data Analysis Method", Sosyoekonomi, 29(50), 95-108.

economic recycling will be more than 1 unit. Another variable is education expenditures. Today, in the world of technology and competitive conditions, it is known that the quality of the workforce is more important than quantity. It is known that the aim is to produce high value-added products and services rather than the number of products and services both at the country level and at the level of companies. The only condition for producing high valueadded products in society is an educated and trained population. In this direction, parallel to the findings obtained in the model, it is predicted that the transformation into the economy will be more than 1 unit against one unit of resource spent for education. As a result, it is seen that a country needs a healthy population, an educated workforce, and high value-added products and services for economic development, and these variables have a substantial effect on economic growth.

\section{References}

Aghion, P. \& P. Howitt (1996), "Research and development in the growth process", Journal of Economic Growth, 1(1), 49-73.

Akcali, B.Y. \& E. Sismanoglu (2015), "Innovation and the effect of research and development (R\&D) expenditure on growth in some developing and developed countries", ProcediaSocial and Behavioral Sciences, 195, 768-775.

Bakare, A.A. \& S. Olubokun (2011), "Health care expenditure and economic growth in Nigeria: An empirical study", Journal of Emerging Trends in Economics and Management Sciences, 2(2), 83-87.

Baltagi, B.H. (2013), Econometric analysis of panel data, Chichester: John Wiley \& Sons.

Barro, R.J. (2001), "Education and economic growth", in: J.F. Helliwell (ed.), The contribution of human and social capital to sustained economic growth and well-being, OECD, 13-41.

Bhargava, A. \& D.T. Jamison \& L.J. Lau \& C.J. Murray (2001), "Modeling the effects of health on economic growth", Journal of health economics, 20(3), 423-440.

Bozkurt, C. (2015), "R\&D expenditures and economic growth relationship in Turkey", International Journal of Economics and Financial Issues, 5(1), 188.

Brien, R.M. (2007), “A caution regarding rules of thumb for variance inflation factors”, Quality \& Quantity, 41(5), 673-690.

Chang, K. \& Y.H. Ying (2006), "Economic growth, human capital investment, and health expenditure: a study of OECD countries", Hitotsubashi Journal of Economics, 1-16.

Chatterji, M. (1998), “Tertiary education and economic growth”, Regional Studies, 32(4), 349-354.

Elmi, Z.M. \& S. Sadeghi (2012), "Health care expenditures and economic growth in developing countries: panel co-integration and causality", Middle-East Journal of Scientific Research, 12(1), 88-91.

Falk, M. (2007), "R\&D Spending in the High-Tech Sector and Economic Growth", Research in Economics, 61(3), 140-147.

Goel, R.K. \& J.E. Payne \& R. Ram (2008), "R\&D expenditures and US economic growth: A disaggregated approach", Journal of policy modeling, 30(2), 237-250. 
Gökkaya, D. \& O. Şenol \& Ü. Çıraklı (2021), "Investigation of the Effect of R\&D, Education and Health Expenditures on Economic Growth by Panel Data Analysis Method", Sosyoekonomi, 29(50), 95-108.

Griffith, R. (2000), "How important is business R\&D for economic growth and should the government subsidise it?", IFS Briefing Note, No. 12, The Institute for Fiscal Studies, London.

Gujarati, D.N. (2004), Basic econometrics, McGraw Hill: New York.

Güven, D. \& T. Şimşek \& A. Güven (2018), "Sağlık Yönetimi Kapsamında Sağlık Harcamalarının Ekonomik Büyüme Üzerine Etkisi: MENA Ülkeleri Üzerine Bir Panel Regresyon Analizi”, Sosyoekonomi, 26(37), 33-55.

Gyimah-Brempong, K. \& O. Paddison \& W. Mitiku (2006), "Higher education and economic growth in Africa", The Journal of Development Studies, 42(3), 509-529.

Gylfason, T. (2001), "Natural resources, education, and economic development", European economic review, 45(4-6), 847-859.

Hanushek, E.A. \& L. Woessmann (2010), “Education and economic growth", Economics of education, 60-67.

Heshmati, A. (2001), "On the Causality Between GDP and Health Care Expenditure in Augmented Solow Growth Model”, SSE/EFI Working Paper Series in Economics and Finance, No. 423.

Hongyi, L.I. \& L. Huang (2009), "Health, education, and economic growth in China: Empirical findings and implications", China Economic Review, 20(3), 374-387.

Kurt, S. (2015), "Government health expenditures and economic growth: a Feder-Ram approach for the case of Turkey", International Journal of Economics and Financial Issues, 5(2), 441447.

Mansfield, E. (1972), "Contribution of R\&D to economic growth in the United States", Science, 175(4021), 477-486.

Mariana, D.R. (2015), "Education as a determinant of the economic growth: The case of Romania", Procedia-Social and Behavioral Sciences, 197, 404-412.

Mayer, D. (2001), "The long-term impact of health on economic growth in Latin America", World development, 29(6), 1025-1033.

Mercan, M. \& S. Sezer (2014), "The effect of education expenditure on economic growth: The case of Turkey", Procedia-Social and Behavioral Sciences, 109, 925-930.

Mishra, P.K. \& S.K. Mishra (2015), "The Triangulation Dynamics between Education, Health and Economic Growth in India", The Journal of Commerce, 7(2), 69.

Pessoa, A. (2010), "R\&D and economic growth: How strong is the link?", Economics Letters, $107(2), 152-154$

Piabuo, S.M. \& J.C. Tieguhong (2017), "Health expenditure and economic growth-a review of the literature and an analysis between the economic community for central African states (CEMAC) and selected African countries", Health economics review, 7(1), 1-13.

Rivera IV, B. \& L. Currais (1999), "Economic growth and health: direct impact or reverse causation?", Applied Economics Letters, 6(11),761-764.

Romer, P.M. (1989). "Human capital and growth: Theory and evidence", NBER Working Paper, 3173, National Bureau of Economic Research, Cambridge, Mass.

Samimi, A.J. \& S.M. Alerasoul (2009), "R\&D and economic growth: New evidence from some developing countries", Australian Journal of Basic and Applied Sciences, 3(4), 34643469. 
Şen, H. \& A. Kaya \& B. Alpaslan (2018), "Education, Health, and Economic Growth Nexus: A Bootstrap Panel Granger Causality Analysis for Developing Countries", Sosyoekonomi, 26(36), 125-144.

Stevens, P. \& M. Weale (2004), "Education and economic growth", International handbook on the economics of education, 27, 205-311.

Stokey, N.L. (1995), "R\&D and economic growth", The Review of economic studies, 62(3), 469-489.

Sylwester, K. (2001), "R\&D and economic growth”, Knowledge, Technology \& Policy, 13(4), 71-84.

Tamang, P. (2011), “The impact of education expenditure on India's economic growth", Journal of International Academic Research, 11(3), 14-20.

Wang, K.M. (2011), "Health care expenditure and economic growth: Quantile panel-type analysis", Economic Modelling, 28(4), 1536-1549.

Woo, Y. \& E. Kim \& J. Lim (2017), “The impact of education and R\&D investment on regional economic growth", Sustainability, 9(5), 676. 